\title{
Tuberculous Meningitis at the Department of Child Health Dr. Pirngadi Hospital, Medan
}

\author{
by \\ MARGARETHA DAMANIK, SRI ZAMZAH, MARDIANA K. DJ \\ $M . D$ MARBUN and B. SAING
}

(From the Department of Child Health, School of Medicine, University of North Sumatera / Dr. Pirngadi Hospital, Medan)

\begin{abstract}
Tuberculous meningitis was studied descriptively in 167 cases (1.19\%) of 14082 bospitalized patients at the Department of Child Health Dr. Pirngadi Hospital, Medan in a period of the years 1985 to 1989.

The bighest incidence was in the age group of under 3 years (46.11\%) consisting $20.78 \%$ of the stage I, 54.55\% stage II, and $24.67 \%$ stage III. The youngest age was five months (2 cases) and the oldest was 14 years old ( 3 cases). The case fatality rate was $27.54 \%$, they were $2.17 \%$ stage I, $32.61 \%$ stage $I$, and $65.22 \%$ stage III. Stage III showed bigher mortality rate than stage I and II ( $p<0.001)$. The most frequent symptom was conurlsion (43.71\%) followed by fever (33.53\%).

Contact with patients who bad pulmonary tuberculosis were found in $56.28 \%$. Positive tuberculin test was found in $17.96 \%$ and pulmonary radiological abnormalities in $57.48 \%$.

The bighest number of cases (51.50\%) was group with cerehrospinal fluid cell count of $101-500 / \mathrm{mm}^{3}$. Cases which never got BCG immunization comprised $83.83 \%$. The nutritional states on admission to the bospital were miid/ moderate malnutrition in $67.07 \%$ and severe malnutrition in $32.93 \%$.
\end{abstract}




\section{Introduction}

Tuberculous meningitis is an inflammation of meningen as a result of primary tuberculous complication. The most important primary focus was the lung, although it may occur in other origins such as, lymphnodes, bones, nasal sinus and gastrointestinal tract [1].

In Indonesia, tuberculous meningitis remains the most frequent disease in children, since the incidence is high [2]. The prevalence of patients with pulmonary tuberculosis by the 1980 survey in North Sumatera was $0.44 \%$ of population, where the highest incidence was in babies and young children [3]. Appropiate care, early treatment, and regular long term therapy were needed to cure and to prevent sequelae. Tuberculous meningitis without treatment is fatal [4].

The purpose of this study is to evaluate the morbidity and mortality rates and the clinical pattern of tuberculous meningitis in a period of 5 years (1985 - 1989) at the Department of Child Health, School of Medicine, University of North Sumatera/Dr. Pirngadi Hospital, Medan.

\section{Materials and methods}

This study was designated restrospectively on cases of hospitalized patients in a period from January 1985 to December 1989 at the Department of Child Health, School of Medicine, University of North Sumatera/Dr. Pirngadi Hospital, Medan, using all medical records with the diagnosis of serous meningitis.

The diagnosis was established by anamnesis, clinical examination (if within 2 weeks of treatment they had complete recovery, the diagnosis was non tuberculous serous meningitis and they were excluded from this study: but, if after more than 2 weeks there was no improvement they were diagnosed as tuberculous meningitis), radiological examinations and laboratory findings without bacteriological study.

The stages of this disease were classified by Lincoln's criteria. The nutritional state of the patients was classified by the PCM (protein calorie malnutrition) classification as by recommended by the 1975 Anthropometric Seminar (Lokakarya Antropometri 1975). For statistical analysis the Chi Square test was used with significance level of 0.05 .

\section{Results}

Of the 14.082 cases admitted during 5 years (Jan, 1985 - December, 1989), 169 cases were serous meningitis, out of which 167 (1.19\%) were tuberculous meningitis. Two cases of serous meningitis of non-tuberculous origin and were therefore excluded from the study .
Table II shows that most of the patients with tuberculous meningitis $(76,65 \%)$ were in the age group of under five years, and the highest was in the age group of 0 to 3 years. But, there was no significant difference between males and the females $(p>0.05)$. 
Table I. Incidence of Tuberculous Meningitis

\begin{tabular}{|lccc|}
\hline Year & Number of patients & Cases & $\%$ \\
\hline 1985 & 2269 & 38 & 1.67 \\
1986 & 2979 & 40 & 1.34 \\
1987 & 3114 & 49 & 1.57 \\
1988 & 3370 & 21 & 0.62 \\
1989 & 2350 & 19 & 0.81 \\
\hline Total : & 14082 & 167 & 1.19 \\
\hline
\end{tabular}

Table II. Distribution of Tuberculous Meningitis According to Age and Sex

\begin{tabular}{|lc|cccc|}
\hline \multirow{2}{*}{ No } & Age (yrs) & \multicolumn{4}{|c|}{ C a s e s } \\
\cline { 3 - 6 } & & Female & Male & Total & $\%$ \\
\hline 1. & $0-3$ & 36 & 41 & 77 & 46.11 \\
2. & $3-6$ & 16 & 35 & 51 & 30.54 \\
3. & $6-9$ & 7 & 10 & 17 & 10.18 \\
4. & $>9$ & 11 & 11 & 22 & 13.17 \\
\hline \multicolumn{2}{l|}{ Total : } & 70 & 97 & 167 & 100.00 \\
\hline
\end{tabular}

$\mathrm{p}>0.05$

Table III. Symptoms of Tuberculous Meningitis

\begin{tabular}{|lcc|}
\hline Complaints & Number of Cases & $\%$ \\
\hline Convulsions & 108 & 64.67 \\
Fever & 98 & 58.68 \\
Decreased consciousness & 80 & 47.90 \\
Vomiting & 21 & 12.57 \\
Cough & 9 & 5.39 \\
Paralysis & 6 & 3.59 \\
Dyspnea & 5 & 2.99 \\
Neck stifness & 3 & 1.79 \\
Diarrhea & 3 & 1.79 \\
Headache & 3 & 1.79 \\
\hline
\end{tabular}

Table IV. Other Findings in Patients with Tuberculous Meningitis

\begin{tabular}{|lccc|}
\hline Examination & \multicolumn{3}{c|}{ R e s u l t } \\
\cline { 2 - 4 } & Positive & Uncertain & Negative \\
\hline $\begin{array}{l}\text { Contact with patients } \\
\text { who had Pulmonary Tuber } \\
\text { culosis }\end{array}$ & 94 & 28 & 45 \\
Abnormality on X-ray & $(56.28 \%)$ & $(16.76 \%)$ & $(26.95 \%)$ \\
(Rontgenogram) & 96 & 45 & 26 \\
Tuberculin Test & $(57.48 \%)$ & $(26.95 \%)$ & $(15.57 \%)$ \\
& 30 & - & 128 \\
BCG & $(17.96 \%)$ & - & $(76.65 \%)$ \\
& 27 & - & 140 \\
& $(16.17 \%)$ & & $(83.83 \%)$ \\
\hline
\end{tabular}

Table V.Nutritional Status on Admission of Patients with Tuberculous Meningitis

\begin{tabular}{|ccccc|}
\hline & & \multicolumn{3}{c|}{ Malnutrition } \\
\cline { 3 - 5 } Age (yrs) & Wellnourished & Mild/Moderate & Severe & Total \\
\hline $0-3$ & - & 53 & 22 & 75 \\
$3-6$ & - & 39 & 13 & 52 \\
$6-9$ & - & 10 & 7 & 17 \\
$>9$ & - & 10 & 13 & 23 \\
Total : & - & $(67.07 \%)$ & $(32.93 \%)$ & 167 \\
& & & 55 & \\
\hline
\end{tabular}

In this study the clinical findings were $(76.65 \%)$, and most of the patients $(140$ in $108(64.67 \%)$ with convulsions, 98 cases $=83.83 \%)$ had had no BCG vacci(58.68\%) with fever, and 80 (47.90\%) with decreased consciousness.

Table IV shows that 94 cases $(56.28 \%)$ had contact with patients who had pulmonary tuberculosis, and 96 (57.48\%) had abnormalities on the Rontgenograms. Tuberculin test was negative in 128 cases nation at all.

Table $\mathrm{V}$ demonstrates that most of the cases had mild/moderate malnutrition, namely in 112 cases $(67,07 \%)$, and severe malnutrition was found in 55 cases (32.93\%), while none was, in a good nutritional state. 
Table VI. Cerebrospinal Fluid Cell Count

\begin{tabular}{|ccc|}
\hline Number of Cells/mm3 & Number of Cases & $\%$ \\
\hline $10-100$ & 68 & 40.72 \\
$101-500$ & 86 & 51.50 \\
$501-1000$ & 8 & 4.79 \\
$>1000$ & 5 & 2.99 \\
\hline
\end{tabular}

Table VII. Distribution of Tuberculous Meningitis According to Age and Stage of the Disease

\begin{tabular}{|lcccc|}
\hline Age (yrs) & Number of Cases & \multicolumn{3}{c|}{ S t a g e s } \\
\cline { 3 - 5 } & & I & II & III \\
\hline $0-3$ & 77 & 16 & 42 & 19 \\
$3-6$ & 51 & 19 & 20 & 12 \\
$6-9$ & 17 & 4 & 11 & 2 \\
$>9$ & 22 & 4 & 9 & 9 \\
\hline Total & 167 & 45 & 82 & 42 \\
& & $(25.75 \%)$ & $(49.10 \%)$ & $(25.15 \%)$ \\
\hline
\end{tabular}

$p>0.05$

Table VIII.Association between Outcome and the Stages of Tuberculous Meningitis

\begin{tabular}{|lcccc|}
\hline Outcome & \multicolumn{3}{c|}{ S t a g e } & Total \\
\cline { 2 - 4 } & I & II & III & \\
\hline Survived & 42 & 67 & 12 & 121 \\
Died & 1 & 15 & 30 & 46 \\
\hline Total : & 43 & 82 & 42 & 167 \\
& $(2.33 \%)$ & $(18.29 \%)$ & $(71.43 \%)$ & \\
\hline $\mathrm{X}^{2}=57.748$ & $\mathrm{df}=2$ & $\mathrm{p}<0.001$ & & \\
\hline
\end{tabular}

This study demonstrated that the nificance found $(p>0.05)$. highest number of cases was group with cerebrospinal fluid cell count of 101$500 / \mathrm{mm}^{3}$, namely in 86 cases $(51.50 \%)$

Death were found in 1 of 43 patients of stage I (12.33\%), 15 of 82 patients of stage This study demonstrated that most of $(71.43 \%)$. 30 of 42 patients of stage the patients were in stage II $(82$ cases $=$ sociated with the mortality $(\mathrm{p}<0.001)$.

$49.10 \%)$, but there was no statistical sig-
Table IX. Mortality of Tuberculous Meningitis by Age

\begin{tabular}{|cccc|}
\hline Age (yrs) & Number of Cases & Mortality & $\%$ \\
\hline $0-3$ & 77 & 21 & 27.27 \\
$3-6$ & 51 & 13 & 25.49 \\
$6-9$ & 17 & 7 & 41.17 \\
$>9$ & 22 & 5 & 22.73 \\
\hline Total : & 167 & 46 & \\
& & $(27.54 \%)$ & \\
\hline
\end{tabular}

Table X. Association of Nutritional State and Fatality

\begin{tabular}{|lcll|}
\hline Nutritional State & Number of Cases & Death & $\%$ \\
\hline Wellnourished & & - & - \\
Mild/Moderate malnutrition & 112 & 29 & 25.89 \\
Severe malnutrition & 55 & 17 & 30.90 \\
\hline Total : & 167 & 46 & \\
\hline P $>0.5$ & & &
\end{tabular}

Table IX shows the mortality rate of $27.54 \%$. Although most of the cases was found in the age oroup of 0 to 3 years,

the highest age specific fatality rate was

Table $X$ shows that the nutritional found in the age group of 6 to 9 years.

\section{Discussion}

In the last five years, the number of pa- in the age group of under years (1987tients with tuberculous meningitis admit- 1982), and Komalarini (1974-1983) reportted, ranged from 19 to 49 per-year with a ed $87.60 \%$ in the age group of under five prevalence of $1.9 \%$. Jo Kian Tjaj (1964- years [6,7,8,9]. This may be caused by 1972) found $1.14 \%$ of all hospitalized cas- the fact that the children in this age es while Bistok Saing (1987-1982) found group are still in close contact to with $1.14 \%$ and Salmin (1980-1984) $1.23 \%$ of their parents, who might be the source of all cases/years $[5,6,7]$.

Most of them (46.11\%) were in the age group of under 3 years. This condition had also been reported by others like Sondang Tambunan (1979) who reported the age group of under 3 years in $55.81 \%$, Salmin (1980-1984) found $51.96 \%$, but Bistok Saing reported $60.60 \%$ states was not associated with the mortalin patients with tuberculous meningi$(p>0.05)$ infection, or, it may be associated with the low body defence mechanisme in this age group.

In general, patients admitted to the Department of Child Health, Dr. Pirngadi Hospital, Medan were in the advanced stage (stages II for $49.10 \%$ and stage III for $25.15 \%$ ). 
The mortality was associated with the stage of disease during treatment (Table VIII). In this study the case fatality rate was $27.54 \%$ ( 46 patients). Salmin (19801984) reported a figure of $28.92 \%$, Bistok Saing (1978-1982) 39\%, Sondang Tambunan (1979) $37.21 \%$, and Jo Kian Tjaj (1964-1972) $47.8 \%$ [5,6,7,8].

Of the 46 fatal cases, stage III had the highest mortality rate $(65.22 \%)$, followed by stage II (32.61\%), and stage I (2.17\%). Salmin reported (1980-1984) that the mortality rate of stage III was $30.43 \%$, stage II $27.50 \%$, and stage I $22.22 \%$. Sondang Tambunan (1979) reported the mortality rate of Stage III $23.26 \%$, stage II $10 \%$, and stage I 0\% (8). According to Nelson the mortality rate of stage III was $68.4 \%$, and $15 \%$ for stage II. The higher mortality rate was found in the more advanced stages with a statistically significant difference $(p<0.001)$. This study demonstrated the existence of a history of contact with pulmonary tuberculosis in 56.28\%, Salmin (1980-1984) reported $37.25 \%$ and Son- dang Tambunan (1979) 83.72\% [7,8].

In this study, lung disorders confirmed by thorax rontgenograms were found in $57.48 \%$ and this is quite similar to what was reported by Salmin (60.29\%) [7]

Tuberculin test is one of the diagnostic procedures in children who have tuberculous Mycobacterium (10). In our cases, only $17.96 \%$ showed a positive test. Salmin (1980-1984) reported $8.82 \%$, and Sondang Tambunan $6.97 \%$ [7,8]

This might be due to the severe tuberculous meningitis and the fact that paients usually come in the advanced stage of their disease so that the tuberculin test may be negative, because of the anergic reaction [4]. There may be another possibility for the negative tuberculin test, namely, the nutritional state as found in this study revealing that all of the patients were malnourished.

Most of our cases (83.83\%) had had no prior BCG Vaccinations. The change in cerebrospinal fluids (Table VI) was also quite similar to previous studies $[7,8]$.

\section{REFERENCES}

1. Speck WT. Tuberculous Meningitis. In: Behrman RE and Vaughan VC, eds. Nelson Textbook of Paediatrics 13th ed, Philadelphia; WB Saunders, 1987 : 633-4.

2. Bleiker MA. Epidemiological trends of tuberculosis in low and height prevalence Countries. Paediatr Indones 1975; $15: 273-85$.

3. Gunardi AS. Tuberkulosis anak dalam program pemberantasan TB paru nasional. Kumpulan makalah Konika VI Denpasar 1519 Juli 1984: 29-36.

4. Weil ML. Chronic and Granulomatous infection of meninges. In: Menkes JH, eds. Textbook of Child Neurology 3th ed, Lea \& Feibiger, Philadelphia, 1985: 224-6.

5. Kian Tjaj Jo, Saragih R, Halim S, Irawati T, Harnopijati P, Manoeroeng S.M, and Sitompul OVN. Tuberculosis in children and BCG Vaccination in north Sumatera. Paediatr Indones 1975; 15: 303-14.

6. Saing B, Lubis IZ and Siregar H. Meningitis tuberkulosa selama 5 tahun di Bagian Ilmu
Kesehatan Anak R.S. Dr. Pirngadi Medan Kumpulan Naskah Kongres Nasional III IDPI Medan 21-23 Desember 1983: 195-201.

7. Salmin OB, Guslihan DT, Saing B dan Siregar $\mathrm{H}$. Meningitis Tuberkulosa di Bagian Ilmu Kesehatan anak FK USU RS Dr. Pirngadi Medan periode 1980-1984. Presented at the $7^{\text {th }}$ National Congres of Paediatrics, Jakarta 1987.

8. Tambunan S, Adi S, Noeriman AY, Saat R. Tuberculosis Meningitis at the Department of Child Health Dr. Pirngadi Hospital Medan (1979). Paediatr Indones 1984; 24: 165-72.

9. Komalarini S, Suiliani S and Wulur H. Pengalaman Pengobatan Meningitis Tuberkulosa. Medika No. 1 Januari 1985; 11: 59-62.

10. Rahajoe NN, Rahajoe N, Boediman I, Said $M$ and Lazuardi S. The treatment of Tuberculous Meningitis in children with a combination of Isoniazed, Rifampicin and Streptomycin (A preliminary report). Paediat Indones 1979; 19: 285-94.

\section{Conclusions}

1. Of the 14082 hospitalized cases in a pe- normal rontgenograms of the chest riod of 5 years, $1.19 \%$ had tuberculous 5. Most of the cases $(83.83 \%)$ had had no meningitis.

2. The highest incidence (46.11\%) was found in the age group of 0 to 3 years. prior BCG vaccination.

of the patients were malnourished 7. The case fatality rate was $27.54 \%$, and (67.07\%), the mortality though, was not associated with the nutritional state.

the highest rate was found in patients with Stage III of their disease (65.22\%).

4. Most of the patients (57.48\%) had ab- 1. Speck WT. Tuberculous Meningitis. In: Behr- 